\title{
Optical Characterization of CB Deposited CdZnS Thin Films
}

\author{
Angad Nagorao Jadhav ${ }^{1, *}$ and Maheshwar Mallikarjun Betkar ${ }^{2}$ \\ ${ }^{1}$ Yeshwant Mahavidyalaya, Nanded-431602, MS, India \\ ${ }^{2}$ Shri Kumarswami Mahavidyalaya, Ausa, Dist. Latur-413520, MS, India \\ ${ }^{*}$ Corresponding author
}

\begin{abstract}
Cd}_{1-\mathrm{x}} \mathrm{Zn}_{\mathrm{x}} \mathrm{S}$ thin films were deposited by Chemical Bath Deposition (CBD) in aqueous medium onto bare silicon glass substrates, The synthesized thin films were characterized by UVVisible spectrophotometer for optical studies. The energy band gap of $\mathrm{Cd}_{1-\mathrm{x}} \mathrm{Zn} \mathrm{n}_{\mathrm{x}} \mathrm{S}$ thin films deposited for different reagent concentration in the bath solution was determined from UV-VIS absorption data. The band gap energy and optical transmissions were studied under optimum parametric conditions. The band gap was increased with $\mathrm{Zn}$ content from 2.7 to $3.9 \mathrm{eV}$.
\end{abstract}

\section{Keywords-Cd $\mathrm{Zn}_{1-\mathrm{x}} \mathrm{S} ;$ band gap; optical characterization}

\section{INTRODUCTION}

Increasing world's population and demands of utilization of natural resources causes serious problems of energy crises in near future. All the reservoirs of fossil fuels, coal, oil and natural gases are going to exhausts at the end of century.

Now day solar cell devices play vital role in converting solar energy into usable form. The science and technology of photovoltaic devices (solar cells) and systems have undergone revolutionary developments. Many type of thin film solar cells exists today; the major contributors being crystalline silicon, amorphous crystalline gallium-arsenide, poly-crystalline copper-indium gallium di-sellenide (CuIGS) and polycrystalline cadmium telluride ( $\mathrm{CdTe})[1-8]$.

In the past few years, II-IV semiconductors thin films have attracted considerable attention from the research community because of their wide range of applications in the fabrication of solar cells and other electronic and opto-electronics devices. Cadmium (CdS) is mostly used as a window layer for photo voltaic devices.

Cadmium sulphide (CdS) is an important n-type semiconductor with a low direct band gap used as window layer material in solar cell devices. CdS absorbs blue portion of solar radiations and decrease the current density of solar cells. Doping with $\mathrm{Zn}$ to $\mathrm{CdS}$ window material improves the electrical and optical properties of thin films. The CdZnS provides the wider band gap and higher optical transmittance as compared to CdS. The efficiency of solar cell devices is fund to be enhanced by increasing the band gap of buffer layer.

Out of available thin film deposition technique, the most simple and non-vacuum technique Chemical Bath Deposition (CBD) is implemented in present work. It is a low cost and always proffered for larger surface area deposition [9-15].
The present study aims with deposition of $\mathrm{Cd}_{\mathrm{x}} \mathrm{Zn}_{1-\mathrm{x}} \mathrm{S}$ thin films by using chemical bath deposition Technique (CBD) and to study the synthesized thin films optically for investigating the effect of $\mathrm{Zn}$ doping on the optical properties.

\section{EXPERIMENTAL}

The $\mathrm{Cd}_{\mathrm{x}} \mathrm{Zn}_{1-\mathrm{x}} \mathrm{S}$ thin films were synthesized by simple Chemical Bath Deposition technique. Cadmium chloride $\left(\mathrm{CdCl}_{2}\right)$, zinc chloride $\left(\mathrm{ZnCl}_{2}\right)$ and thiourea $\left(\mathrm{NH}_{2} \mathrm{CSNH}_{2}\right)$ were used as $\mathrm{Cd}^{+2}, \mathrm{Zn}^{+2}$ and $\mathrm{S}^{-2}$ ions respectively. The stock precursors of $\mathrm{CdCl}_{2}(0.25 \mathrm{M}), \mathrm{ZnCl}_{2}(0.25 \mathrm{M})$ and $\mathrm{NH}_{2}-\mathrm{CS}$ $\mathrm{NH}_{2}(0.3 \mathrm{M})$ were prepared. The experimental precursors with different proportions were employed in reaction beaker for deposition of $\mathrm{Cd}_{\mathrm{x}} \mathrm{Zn}_{1-\mathrm{x}} \mathrm{S}$.

The $\mathrm{pH}$ of the solution was adjusted to 11 by adding the aqueous $\mathrm{NH}_{3}$. The reaction beaker was kept in temperature bath, maintained at constant $80^{\circ} \mathrm{C}$. Glass substrates were cleaned by $24 \mathrm{hr}$ immersion in chromic acid, rinsed with acetone and double distilled water. The experimental bare glass substrates were mounted on substrate holder and immersed in the reaction beaker. The substrate holder was rotated at slow speed $(45 \mathrm{rpm})$ by means of Direct Current geared motor for 30 minutes. The $\mathrm{pH}$ of the precursor, reaction temperature, rotation speed and dipping time of the substrate were kept constant throughout the experiment at optimized values. The thin, uniform $\mathrm{Cd}_{\mathrm{x}} \mathrm{Zn}_{1-\mathrm{x}} \mathrm{S}$ films were obtained at the end of the reaction process.

TABLE I. SYNTHESIZED $\mathrm{CD}_{\mathrm{x}} \mathrm{ZN}_{1-\mathrm{X}} \mathrm{S}$ FILM SAMPLES

\begin{tabular}{|c|c|c|c|}
\hline \multirow{2}{*}{$\begin{array}{c}\text { Compositi } \\
\text { on } \mathrm{x}\end{array}$} & \multicolumn{3}{|c|}{ Deposition Precursors } \\
\cline { 2 - 4 } $\mathrm{CdCl}_{2}(\mathrm{ml})$ & $\mathrm{ZnCl}_{2}(\mathrm{ml})$ & $\mathrm{NH}_{2} \mathrm{CSNH}_{2}(\mathrm{ml})$ \\
\hline 0.0 & 5 & 0 & 5 \\
\hline 0.2 & 4 & 1 & 5 \\
\hline 0.4 & 3 & 2 & 5 \\
\hline 0.6 & 2 & 3 & 5 \\
\hline 0.8 & 1 & 4 & 5 \\
\hline 1.0 & 0 & 5 & 5 \\
\hline
\end{tabular}

The different sets of $\mathrm{Cd}_{\mathrm{x}} \mathrm{Zn}_{1-\mathrm{x}} \mathrm{S}$ thin films were prepared. Synthesized films were rinsed with de-ionized water to remove the loosely bound particles and are annealed at $100{ }^{\circ} \mathrm{C}$ for three hours. The synthesized $\mathrm{Cd}_{\mathrm{x}} \mathrm{Zn}_{1-\mathrm{x}} \mathrm{S}$ films were subjected to optical characterizations to study the effect of $\mathrm{Zn}$ content. All the $\mathrm{Cd}_{\mathrm{x}} \mathrm{Zn}_{1-\mathrm{x}} \mathrm{S}$ thin films were prepared on optimizing the bath parameters. 

Table I.

The deposition parameters are summarized in following

\section{OPTICAL CHARACTERIZATIONS OF $\mathrm{CD}_{\mathrm{X}} \mathrm{ZN}_{1-\mathrm{x}} \mathrm{S}$ THIN FILMS}

Absorbance data of $\mathrm{Cd}_{\mathrm{x}} \mathrm{Zn}_{1-\mathrm{x}} \mathrm{S}$ thin films was recorded by using UV-Visible spectrophotometer (Systronics Double Beam 2201). The energy band gap of CdS films deposited for different reagent concentration in the bath precursors was determined from UV-VIS absorption data. The band gap was obtained by plotting $(\alpha h v) 2$ versus photon energy $(h v)$ and extrapolating the straight-line portion to $\alpha=0$ and shown in following Figure I. The optical band gap was plotted as a function of concentration of $\mathrm{CdCl}_{2}$. It is clear from the figure that the energy band gap initially increases in linear manner, with reagent concentration. When concentration $0.225 \mathrm{M}$ to

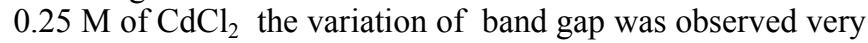
less and thereafter band gap increased. The film deposited for $0.25 \mathrm{M}$ concentration $\mathrm{CdCl}_{2}$ exhibits the higher crystalline nature with minimum grain size. However band gap obtained was $2.8 \mathrm{eV}$ which is greater than band gap of bulk CdS $(2.42$ $\mathrm{eV})$ this is due to quantum confinement effect of the grains.

The reagent concentration or $\mathrm{S} / \mathrm{Cd}$ ratio of the bath solution effectively control the growth rate of the CdS thin film. Following Figure I revels the band gap variation.

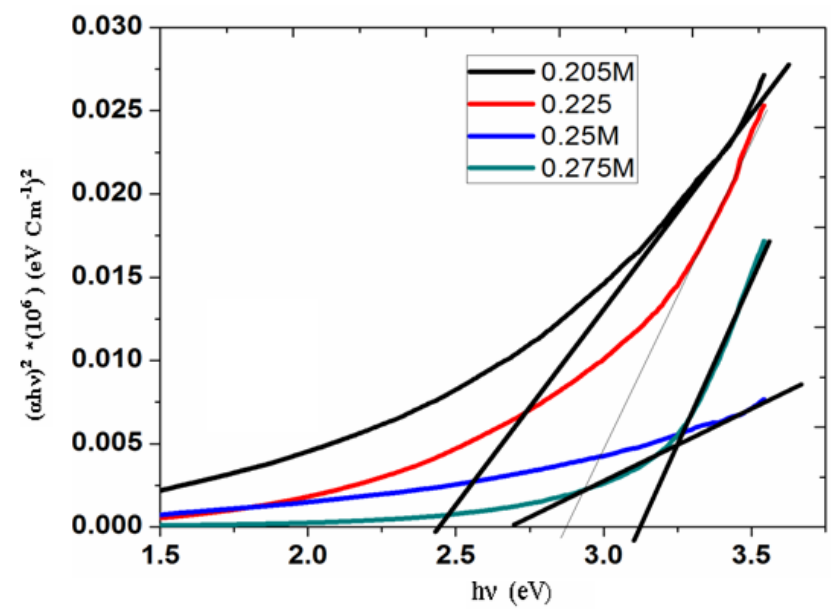

FIGURE I. OPTICAL BANDGAP VARIATION OF $\mathrm{CD}_{\mathrm{X}} \mathrm{ZN}_{1-\mathrm{X}} \mathrm{S}$ THIN FILMS

Extrapolating the straight line portion of the $(\alpha h v)^{2}$ versus $(h v)$ to the zero absorption $(\alpha=0)$ gives the band gap (Eg).

\section{RESULTS AND DISCUSSIONS}

The band gap of composition $\left(\mathrm{Cd}_{1.0} \mathrm{Zn}_{0.0} \mathrm{~S}\right)$ is $2.45 \mathrm{eV}$ which is approximate value as that of band gap of bulk CdS material $(2.42 \mathrm{eV})$. The variation of band gap with $\mathrm{Zn}$ content was observed. The band gap was increased with $\mathrm{Zn}$ content from 2.7 to $3.9 \mathrm{eV}$. In the composition $\mathrm{x}=0.2$, the band gap was found to be $3.9 \mathrm{eV}$. The study concludes that particular combination $\mathrm{Cd}_{\mathrm{x}} \mathrm{Zn}_{1-\mathrm{x}} \mathrm{S}(\mathrm{x}=0.2)$ thin film may be used as an ideal alternative window material to $\mathrm{CdS}$ and $\mathrm{ZnS}$ for solar cell devices.
The variation of band gap versus composition (x) was presented observed. The maximum band gap 3.9 was observed for $\mathrm{Cd}_{\mathrm{x}} \mathrm{Zn}_{1-\mathrm{x}} \mathrm{S}$ thin films in the composition $\mathrm{x}=0.2$. The $\mathrm{x}=0.2$ composition having maximum transmittance $78 \%$ show the maximum $3.9 \mathrm{eV}$ optical band gap which may be high enough for solar cell applications. The decrease of grain size effectively tuned the band gap to higher value. This is attributed to quantum confinement effect.

\section{ACKNOWLEDGMENT}

The authors wish to thank to University Grants Commission, WRO, Pune, for sanctioning Faculty Development Scheme and Physics Research Centre, Mahatma Gandhi Mahavidyalaya, Ahmedpur, Distt. Latur, for providing the $\mathrm{Cd}_{\mathrm{x}} \mathrm{Zn}_{1-\mathrm{x}} \mathrm{S}$ thin films CB deposition facility.

\section{REFERENCES}

[1] Huan Ke, et al, "Effect of temperature on structural and optical properties of $\mathrm{ZnS}$ thin films by chemical bath deposition without stirring the reaction bath," Materials Science in Semiconductor Processing, vol. 18, pp. 28-35, 2014.

[2] Jung Hoon Ahn, Kwun Nam Hui, Kwan San Hui, Young Guk Son, and Dong Hyun Hwang, "Structural and optical properties of $\mathrm{ZnS}$ thin films deposited by RF magnetron sputtering," Nanoscale Research Letters, vol.7(2), 2012

[3] Raghad Zein, and Ibrahim Alghoraibi, "Effect of Deposition Time on Structural and Optical Properties of ZnS Nanoparticles Thin Films Prepared by CBD Method ," International Journal of Chem. Tech Research CODEN (USA), vol.6(5), pp. 3220-3227, 2014.

[4] Nada K. Abbas, Lamia K. Abbas, and Suaad A-Muhameed, "Effect Of Thickness on Structural and Optical Properties of ZnxCd1-xS Thin Films prepared by Chemical Spray Pyrolysis," Int. J. Thin Film Sci., vol. 2 (2), pp. 127-132, 2013.

[5] T.O. Berestok, D.I. Kurbatov, N.M. Opanasyuk, A.D. Pogrebnjak, O.P. Manzhos1, and S.M. Danilchenko, "Structural Properties of ZnO Thin Films Obtained by Chemical Bath Deposition Technique," J. of Nano and Elect. Phy vol. 5(1), 2013.

[6] W. Wang, I. Germanenko, and M. Samy El-Shall, "Room Temperature Synthesis and Characterization of Nanocrystalline CdS, ZnS, and CdxZn1-x S," Chemistry of Materials, vol. 14(7), pp. 3028-3033,2002.

[7] S. Ilican, Y. Caglar and M. Caglar, "Effect of the Substrate Temperatures on the Optical Properties of the Cd 0.22 Zn0.78S Thin Films by Spray Pyrolysis Method," Physica Macedonica, vol. 56, pp. 4348, 2006.

[8] Jie Cheng, DongBo Fan, Hao Wang, BingWei Liu, YongCai Zhang, and Hui Yan,"Chemical bath deposition of crystalline ZnS thin films," Semiconductor Science and Technology, vol.18, (7), 2003.

[9] G. Nabiyouni , R. Sahraei , M. Toghiany, M. H. Majles Ara, and K. Hedayati, "Preparation and characterization of nano- structured $\mathrm{ZnS}$ thin films grown on glass and n-type Si substrates using a new chemical bath deposition technique," Rev.Adv.Mater.Sci., vol. 27 , pp. 52-57, 2011.

[10] I. Nkrumah, F.K. Ampong, B. Kwakye-Awuah, R.K. Nkum, and F. Boakye, "Synthesis and characterization of $\mathrm{ZnO}$ thin films deposited by chemical bath technique," International Journal of Research in Engineering and Technology, vol.02(12), 2013.

[11] Rakhshani y., Makdisi, and Ramazaniyan, "Electronic and optical properties of flurine-doped tin oxide films," J. Applied Phys., vol. 83, pp.1049-1057, 1998.

[12] Dong Hyun Hwang, Jung Hoon Ahn, Kwun Nam Hui, Kwan San Hui, and Young Guk Son, "Structural and optical properties of $\mathrm{ZnS}$ thin films deposited by RF magnetron sputtering," Nanoscale Research Letters, vol. 7 (26), 2012.

[13] H.M.M.N. Hennayaka, and Ho Seong Lee, "Structural and optical properties of $\mathrm{ZnS}$ thin film grown by pulsed electrodeposition," Thin Solid Films, vol. 548(2), pp. 86-90, 2013. 
[14] Fei-Peng Yu, Sin-Liang Ou, Pin-Chuan Yao, Bing-Rui Wu, and DongSing Wuu, "Structural, Surface Morphology and Optical Properties of ZnS Films by Chemical Bath Deposition at Various Zn/S Molar Ratios," Journal of Nanomaterials, vol. 7, 2014 .

[15] Jayanthi K., Chawla S., Chander H. and Haranath D., "Optical and photoluminescence properties of $\mathrm{ZnS}$ : $\mathrm{Cu}$ nanoparticle thin films as a function of dopant concentration and quantum confinement effect," Crystal Research and Technology, vol. 42, pp. 976-982, 2007.

[16] Suhail, and Mahdi Hasan, "Structural and optical properties of ZnS, PbS, Zn1-xPbxS, ZnxPb1-xS and PbZnxS1-xthin films,"IJPAP,vol. 50(06), 2012.

[17] Kennedy, J., Murmu P.P., Gupta P.S., Carder D.A., Chong S.V., Leveneur J. and Rubanov S., "Effects of annealing on the structural and optical properties of zinc sulfide thin films deposited by ion beam sputtering," Materials Science in Semiconductor, 26 (1), pp. 561-566, 2014.

[18] R S Meshram, R M Thombre, "Structural and Optical Properties of ZnS Thin Films Deposited by Spray Pyrolysis Technique," IJCA, vol. 22, 2012.

[19] Nagarani Nagayasamy, Saroja Gandhimathination, and Vasu Veerasamy, "The Effect of $\mathrm{ZnO}$ Thin Film and Its Structural and Optical Properties Prepared by Sol-Gel Spin Coating Method," Open Journal of Metal, vol.3 (2B), 2013.

[20] Layth M., "Study the Effect of Annealing on Optical and Electrical Properties of ZnS Thin Film Prepared by CO2 Laser Deposition Technique,” Iraqi J. Laser, Vol. 13, pp. 29-35, 2014.

[21] Tae Eun Park, Dong Chan Kim, Bo Hyun Kong, and Hyung Koun Cho, "Structural and Optical Properties of $\mathrm{ZnO}$ Thin Films Grown by RF Magnetron Sputtering on Si Substrates," J. of the Kor. Phy. Soci., vol. 45, pp. S697-S700, 2004.

[22] F Zahedi, R S DarianI, and S M Rozatibull, "Structural, optical and electrical properties of $\mathrm{ZnO}$ thin films prepared by spray pyrolysis: Effect of precursor concentration," Mater. Sci., vol. 37(3), pp. 433-439, 2014.

[23] E. Marquez, E. R. Shaaban, and A. M. Abousehly, "Structural and optical properties of ZnS thin films," Int. J. New. Hor. Phys., vol.1, pp. 17-24, 2014.

[24] M. Ruhul Amin Bhuiyan, M. Monjarul Alam, M. Abdul Momin, "Effect of substrate temperature on the optical properties of thermally evaporated ZnS thin ," Turk J Phys, vol. 34, pp. 43-49, 2010.

[25] Dong Hyun Hwang,Jung Hoon Ahn, Kwun Nam Hui, Kwan San Hui, and Young Guk Son, "Nanoscale Structural and optical properties of $\mathrm{ZnS}$ thin films deposited by RF magnetron sputtering," Res Lett. 7(1), 26,2012 .

[26] Huda Abdullah, Huda Abdullah, Norhabibi Saadah, and Sahbuddin Shaari, "Effect of Deposition Time on ZnS Thin Films Properties by Chemical Bath Deposition (CBD) Techniques," World Applied Sciences Journal, vol.19 (8), pp. 1087-1091, 2012.

[27] F. Lisco, et al, "The structural properties of CdS deposited by chemical bath deposition and pulsed direct current magnetron sputtering," Thin Solid Films, vol. 582, pp. 323-327, 2015.

[28] Eman M. Nasir, “Surface morphology and structural properties of ZnS and ZnS:Al thin films," Int. J. of In. Res. in Sci., Eng. and Tech., vol. 3(1), 2014. 